\title{
4
}

\section{Transitional Justice as Interruption: Adaptive Peacebuilding and Resilience in Rwanda}

\author{
Jennie E. Burnet
}

\section{INTRODUCTION}

More than twenty-five years after the 1994 genocide of Tutsi, Rwanda and its people still struggle with its long-term consequences. Applying resilience theory to recovery from genocide poses several conceptual and moral problems. Many resilience approaches emphasise 'a community's ability to cope with crisis, adapt to hazards, and bounce back with minimal loss and disturbance' (Barrios, 2016: 28; Cutter et al., 2008). Genocide, however, breaks society in a way that can never be repaired. The dead cannot be brought back to life. Women and girls cannot be unraped. Survivors cannot forget the violence they experienced. Genocide makes 'bouncing back with minimal loss and disturbance' impossible. Furthermore, in a society where interdependence, kinship relations, reciprocity and communal forms of life are foundational, mass death destroys far more than lives.

This chapter's case study of the Rwandan genocide and its aftermath highlights how a contextualised resilience model of recovery raises questions about the notion of resilience itself. Anthropological critiques of resilience often focus on the variability of the term and its vague definitions (see, e.g., Barrios, 2016; Foxen, 2010). This volume avoids this trap as all authors proceed from Michael Ungar's definition in Chapter 1: 'When referring to biological, psychological, social and institutional aspects of people's lives, the term "resilience" is best used to describe processes whereby individuals interact with their environments in ways that facilitate positive psychological, physical and social development'. Ungar's definition incorporates individual and systemic components of change in response to violent conflict, crimes against humanity or other gross human rights violations. Yet, it is still largely grounded in conceptions of resilience emerging from trauma theory, which emphasise the qualities or characteristics that allow a community to survive following 
a collective trauma' (Sherrieb et al., 2010: 228). While Ungar's definition embraces complex multi-level systems of interaction, it fails to capture how post-genocide recovery and transitional justice are politicised. Thus, it risks 'depoliticize[ing] processes that are, at heart, deeply political' (Barrios, 2016: 30).

In Rwanda, politics produced the 1994 genocide, so it is no surprise that politics deeply shaped recovery processes. This recovery may have increased resilience by improving ordinary citizens' mental health, creating social institutions that mitigate conflict in non-violent ways and providing 'individuals with the internal and external resources necessary to cope with exceptional and uncommon stressors' (Ungar, Chapter 1). Yet, it also built a strong, centralised state dominated by a single political party and president, both of which were factors that made genocide possible in 1994 (Uvin, 1998). This strong centralised state exemplifies how macro-level systemic change seeks 'to avoid future exposure to stress' that Ungar identifies as central to resilience (Chapter 1). Yet, this transformation risks reinforcing inequalities that already exist and perpetuating vulnerabilities (Barrios, 2016: 32; Holling 1973: 14). In Rwanda, poverty created the context where genocide was possible, and it continued after the genocide with long-term physical and psychological consequences. As anthropologist Barrios (2016: 33) points out, 'postdisaster contexts are moments when political elites and culturally dominant groups attempt to define disaster recovery in ways that align with their socioeconomic interests and sensibilities'. Systemic factors often privilege recovery for some in society over others. In Rwanda, this reality has led to increasing divides between the wealthy and poor, which may overlap with divides between Tutsi and Hutu, and has solidified the Rwandan Patriotic Front (RPF) political party's control over the state and economy. Whether this result constitutes resilience is an open question.

This chapter also considers the implications of adaptive peacebuilding and transitional justice for post-genocide recovery. de Coning (2020: 10) defines adaptive peacebuilding as actively engaging in a structured process to sustain peace and resolve conflicts by employing an iterative process of learning and adaptation'. This definition of adaptive peacebuilding implicitly mobilises key aspects of Galtung's concept of positive peace. For Galtung (1969: 183), 'negative peace' is the 'absence of personal violence', which is an incomplete peace. 'Positive peace', on the other hand, is a complete peace where personal violence, structural violence and cultural violence are absent and society is integrated (Galtung, 1969: 190). In this chapter, I extend de Coning's definition of adaptive peacebuilding to encompass local, grassroots initiatives that contribute to building positive peace and resilient communities. I primarily consider initiatives led by local non-government organisations (NGOs) and 
church-based groups as examples of adaptive peacebuilding in Rwanda's postgenocide period. These efforts exemplify adaptive peacebuilding because they emerged from the genocide and focused on 'process not end-states' (de Coning, 2018: 315-317). Furthermore, they responded directly to ordinary people's immediate needs without promoting other political agendas. This evidence from Rwanda validates the need for peacebuilding approaches that focus on broader notions of positive peace instead of state-building (Autesserre, 2014).

Finally, I examine the disruptive nature of transitional justice for locally 'adaptive peacebuilding' initiatives and the state's use of transitional justice to impose a new, stable (and thus 'resilient') social order on Rwandan society. Yet, this resilience fosters inequality and leaves many important issues related to recovery and long-term peace unresolved. Rwanda is an important case study for understanding the relationships between resilience, adaptive peacebuilding and transitional justice because it became 'emblematic of how peacebuilding and reconciliation emerged as global master narratives of the late twentieth century' (Doughty, 2016: 3). The International Criminal Tribunal for Rwanda (ICTR) became the model for numerous international transitional justice mechanisms, and Rwanda's grassroots courts that prosecuted genocide crimes locally have been held up as models for transitional justice predicated on restorative justice and reconciliation.

\section{THE 1994 GENOCIDE OF TUTSI}

During the genocide, approximately 77 per cent of the Rwandan Tutsi population inside the country was killed between 6 April and 14 July 1994 (Des Forges, 1999: 15). The genocide's triggering event was the assassination of President Habyarimana on the evening of 6 April 1994 when his plane was shot down as it approached to land in Kigali, the capital city. Within hours, special forces units from the Rwandan Armed Forces (RAF) erected roadblocks across Kigali, and Interahamwe militiamen fanned out across the city, hunting down opposition political party leaders and prominent Tutsi politicians. On the morning of 7 April, Interahamwe militias began attacking and killing ordinary Tutsi civilians in Kigali and several other places in the country. By 12 April, genocide had become a nation-wide policy. Between 7 April and 14 July 1994, an estimated 800,000 Rwandans lost their lives in the genocide or ongoing armed conflict between the RAF and the RPF rebel group (United Nations, 1999). The genocide ended when the RPF seized the majority of the country's territory, sending the government responsible for the 
genocide, along with the Interahamwe militias and two million civilians, into exile in neighbouring countries.

Genocidal violence in Rwanda involved enormous amounts of hand-tohand killing as the primary weapons used to dispatch victims were farming tools, such as machetes, hatchets, pruning knives and hoes, or traditional weapons such as spears, arrows and clubs. Local government officials organised and recruited ordinary Hutu civilians to find and kill their Tutsi kin, friends and neighbours. Additionally, perpetrators pillaged property, destroyed homes (see Figure 4.1) and slaughtered stolen livestock. Sexual violence and torture featured centrally in the violence. Post-mortem mutilation of bodies and other public displays of gruesome symbolic violence terrorised victims and potential rescuers while fuelling the passions of the most violent killers among the genocidal mobs.

The genocide took place in the midst of a civil war that began in October 1990 when the RPF, which was founded in Uganda, attacked the country in order to overthrow the government and allow tens of thousands of Rwandan refugees to return home. In 1994, civilians experienced active combat between the RAF and RPF that included heavy artillery in many places, particularly around the capital city. As the RPF took territory, allegations emerged of reprisal killings against Hutu civilians, extrajudicial killings of alleged genocide perpetrators and massacres at public meetings (Des

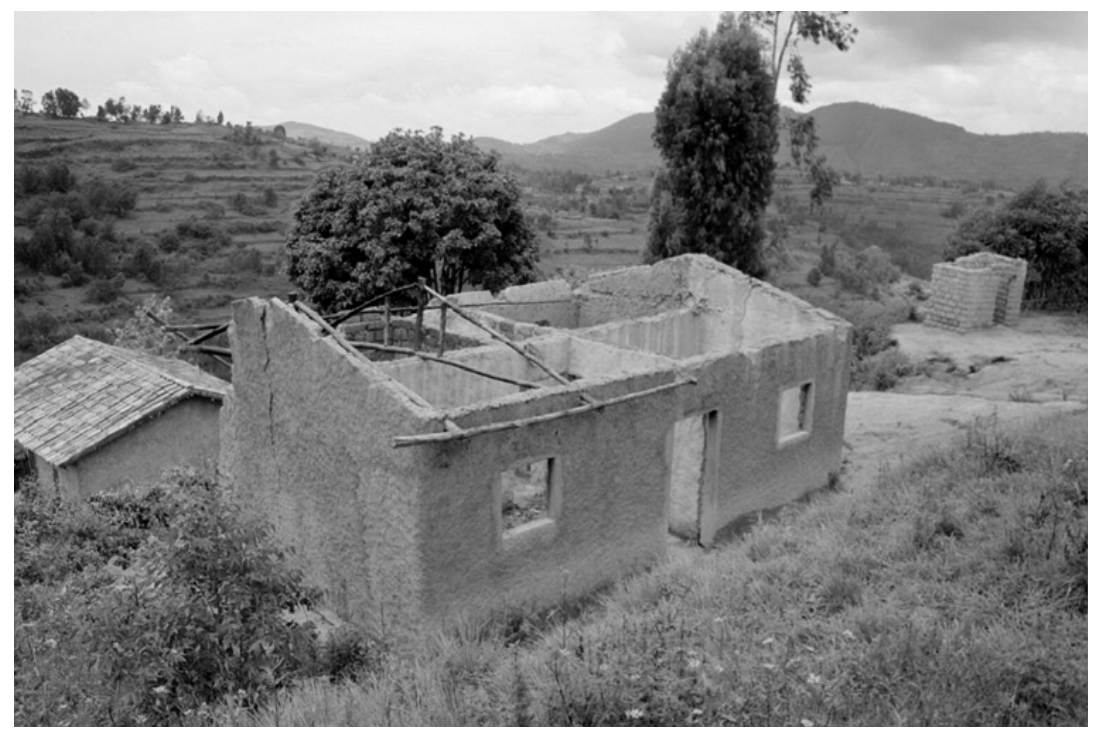

FIGURE 4.1 Destroyed house. Photo by the author. 
Forges, 1999: 542-545). Although some scholars have alleged a 'double genocide', the scale and scope of these killings were incomparable to the genocidal killings that preceded them and have been disproven by at least one study (Verwimp, 2003). Nonetheless, civilian killings by the RPF have largely remained unaddressed through transitional justice mechanisms or public memory institutions.

\section{RELIGIOUS AND SPIRITUAL RESPONSES TO MASS VIOLENCE AS ADAPTIVE PEACEBUILDING}

In the wake of the 1994 genocide, the transitional government faced the near insurmountable task of governing a country with no resources and a traumatised population. The withdrawing government intentionally destroyed the country's physical infrastructure. The genocide and massive exile of civilians more than decimated the country's human resources. Much of the emergency international aid unleashed by images of Rwandan refugees dying of dysentery in eastern Congo went to support refugee camps on the borders of the country instead of the new government and civilians who remained in Rwanda. In the months after the genocide, the new RPF-led government focused on standard, state-centred peacebuilding (as opposed to adaptive peacebuilding) efforts. It sought to stop direct violence, including continued attacks against genocide survivors, reprisal killings and conflicts over property; to appoint civilian administrative authorities; to provide humanitarian relief and to re-establish the rule of law.

Religious leaders, churches and local communities stepped in between the government response and people's spiritual and emotional needs. They organised memorial services and burial ceremonies to remember victims and to give people some culturally relevant means to grieve. While intended simply to respond to people's needs, these activities were forms of adaptive peacebuilding. These religious interventions helped stimulate processes that enabled 'self-organisation' and led to strengthening 'the resilience of social institutions that manage[d] internal and external stressors and shocks' (de Coning, Chapter 11). Barrios (2016: 30-31) calls this phenomenon of civil society stepping into the gap between the state and the people resilience as an antipolitics machine'.

While cultural traditions of mourning may be impossible to practise in the wake of genocide, survivors and others needed to process their grief and honour their lost loved ones. Even though many churches became massacre sites during the genocide and some clergy were responsible for genocide crimes, religious institutions were places where Rwandans of all races 
(Hutu, Tutsi and Twa) came together. During the genocide, the majority of victims had been thrown into pit latrines and inhumed, entombed in mass graves or hastily buried where they lay. Most Rwandans did not know where, when or how their loved ones had died and thus could not perform the necessary religious rituals at their graves. Religious rites such as the consecration of graves remained salient; " $[\mathrm{i}] \mathrm{n}$ the African context, it is unthinkable to honor the dead without religion' (Vidal, 2001: 26; author's translation). In response, many Roman Catholic Church parishes organised community mourning ceremonies for genocide victims' families, friends and neighbours. Local genocide survivor groups mobilised to gather victims' bodies that lay in the open or were discovered in shallow graves and to hold burial ceremonies where priests, pastors or imams consecrated the graves. These community and family-level ceremonies focused on mourning loved ones lost in the violence and honouring religious obligations to the dead (see Figure 4.2). These efforts emerged from local communities and fulfilled local needs (de Coning's first principle of adaptive building, Chapter 11). They were also participatory processes that required clergy, laypeople, survivors and others to cooperate in the organisation of these activities.

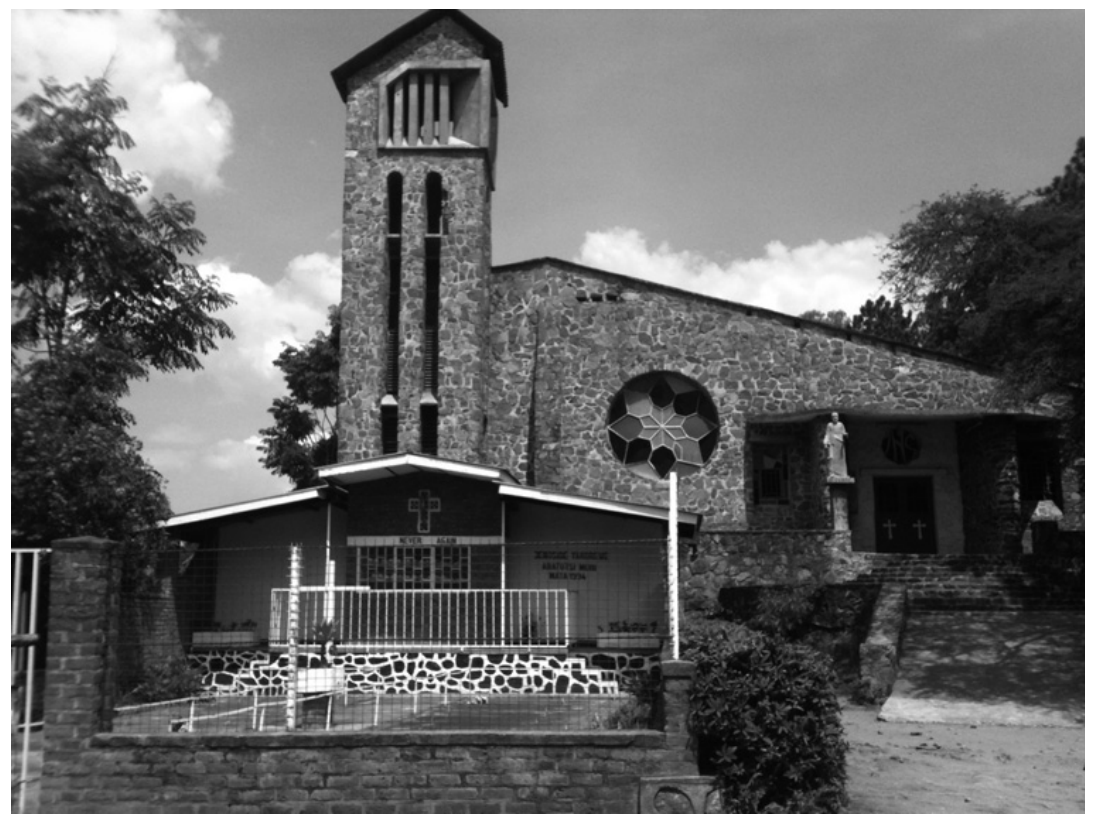

FIGURE 4.2 Kibuye church genocide memorial. Photo by the author. 
Ordinary Rwandans and civil society leaders utilised various cultural resources to adapt to the trauma caused by the genocide and civil war. These included religious beliefs and practices, customs of social accompaniment and patience (kwihangana), gift giving and other forms of reciprocity and traditional conflict-resolution mechanisms. Beyond the burials, commemoration masses and prayer services, ordinary Rwandans drew on a broad range of religious resources to promote healing. Some found solace in singing gospel music and praying alone at home. Others returned to the churches where they prayed before the genocide, not a simple proposition in cases where the spaces had become massacre sites or where clergy had participated in the killings. In the genocide's wake, some survivors renounced churches implicated in the genocide. These survivors gravitated towards charismatic Christian prayer groups, healing worship services or evangelical churches. They found solace in groups that sang gospel music and danced for hours. While these services rarely addressed harm inflicted during the genocide or war, many participants found relief from their ongoing trauma symptoms through their participation in them.

Some Rwandans returned to traditional ancestor or spirit cults, whether alongside or in place of Christianity. Before the genocide, these cults, which the Roman Catholic Church had long maligned and tried to suppress, brought people together across kinship, social group or racial/ethnic lines. In some communities, practitioners of kubandwa or Ryangombe spirit cults resumed their all-night ritual sessions. These seances helped some people address the harms done in the physical realm through the metaphysical intervention of powerful spirits. In this sense, spirituality became a contextually specific resource that enhanced both individual and community resilience.

Several women's organisations, youth associations, church congregations and church-based organisations engaged in post-genocide activities that can be understood as examples of adaptive peacebuilding. Many of these organisations did not set out with reconciliation or peacebuilding as their goals (Burnet, 2012: 179-193). Instead, they intended to help victims of sexual violence, to assist genocide widows, to improve the socio-economic conditions of women or to help people worship. These NGOs recognised that, to help rebuild people's lives after the genocide and war, they must first tackle their material conditions. By addressing the structural violence of poverty, they equipped people to deal with equally vital but more abstract needs, such as psychological health, social isolation or reconciliation. These efforts embody the difference between post-conflict approaches to peacebuilding, which are 'focused on responding to identifiable risks, and the sustaining peace concept 
of peacebuilding, which is aimed at investing in the capacity of societies to manage future tensions themselves' (de Coning, 2018: 313).

\section{EVERYDAY PRACTICES OF COPING AS RESILIENCE AND ADAPTIVE PEACEBUILDING}

Local-level responses to the Rwandan genocide and its aftermath can be understood as organic forms of resistance and adaptive peacebuilding. In the months and years immediately after the genocide, ordinary Rwandans improvised means to put aside their grief and go on living. Some moved to new communities to avoid daily reminders of their experiences during the genocide. Others remarried or gave birth to new children, not to forget those who perished in the genocide but as a way of creating something to live for. Others buried themselves in the minutiae of everyday life; 'a life that slowly regained normalcy with the passage of time, they succeeded at least partially in keeping their memories and the negative emotions attached to them - sadness, anger, guilt, and hatred - at bay' (Burnet, 2012: 75). Despite their best efforts to forget, embodied memories embedded in everyday life, such as an empty bed, the smell of grilled meat or the sight of a machete, broke through their amnesia and transported them back to the genocide. Psychologists might classify these reactions as forms of negative coping (i.e., repressed memories, avoidance, dissociation). Yet, they were adapted to Rwandan understandings of wellness and how to deal with negative life events. Rwandan cultural norms socialise children to hide their tears from strangers because only family members love and care about them (Mironko and Cook, 1996). To be an adult in Rwanda is to be in control, and public displays of emotion are harshly judged. In the Rwandan worldview, talking about bad events from the past risks inviting the spirits that provoked them to return. Furthermore, these everyday practices of coping align with Ungar's (Chapter 1) definition of resilience as 'processes whereby individuals interact with their environments in ways that facilitate positive psychological, physical and social development'.

The genocide had shredded the social fabric. In rural communities, subsistence farmers relied on reciprocity, cooperation and patronage relationships to survive. In the wake of the genocide, these warp threads of daily life were torn. Faced with unimaginable loss and trauma, both physical and psychological, rural Rwandans began to repair the social fabric, often unwittingly, as they muddled through the dire material circumstances in which they found themselves. Women played a central role in these efforts because of their social positions in kin groups and communities (Burnet, 2012: 168-169). At first, neighbours lived together with little to no interaction, or thinly veiled hostility. 
Out of necessity, some women tentatively reached out to former friends, neighbours and colleagues. Slowly, over time, communities began to establish some kind of normalcy in their everyday interactions. They exchanged terse greetings. They borrowed household items or farming equipment. In 2001, women in a rural community described to me how astounded they were that Hutu and Tutsi neighbours had sat next to each other at a recent wedding. They explained that this was unimaginable in 1997, just after many Hutu community members had returned from exile in the Democratic Republic of the Congo. Despite the progress, many survivors actively opposed these and other conciliatory efforts.

These ad hoc processes of getting by, which emerged in the wake of the genocide, can be understood as forms of resilience and adaptive peacebuilding where people adapt to new circumstances out of necessity rather than through formal state or NGO intervention. These efforts helped build social ties through an iterative process, another principle of adaptive peacebuilding (de Coning, Chapter 11). Precisely because these efforts focused on 'process not end-states' and emerged from the devastating change wrought by the genocide, they exemplify adaptive peacebuilding (de Coning, 2018: 315-317). Furthermore, they demonstrate the need for peacebuilding approaches that focus on broader notions of positive peace rather than state-building.

Social accompaniment was an important cultural resource mobilised in the wake of the genocide that helped reweave the social fabric. ${ }^{1}$ During times of hardship, whether illness or death, Rwandans practise social accompaniment to support those facing difficulties. For example, kin, neighbours and friends will visit a sick person at home or in the hospital. These visits provide moral support to the sick and social support for the family. Visitors never come empty-handed; they bring food, beverages or money. Their gifts help the family through the hardships of lost wages or medical costs. Undergirding all Rwandan social interactions is an elaborate system of gift giving and reciprocity. All important social and life events, such as courtship, engagement, marriage, birth, illness or death, are marked by the exchange of gifts. The immense poverty and period of scarcity that followed the genocide made it very difficult for people to maintain these customs. Nonetheless, they continued them through modest or token gifts.

Rwandans also drew on the cultural concept of patience, forbearance or endurance contained in the verb kwihangana (to bear up under) (Burnet,

1 By social accompaniment, I am referring to a local, cultural practice and not accompaniment in social work (Wilkinson and D'Angelo, 2019), pedagogy or international activism (Koopman, 2011). 
2012; Zraly and Nyiranyoye, 2010). Rwandans use this term to talk about their own difficulties, and they encourage each other to endure hardship. For example, a common thing to say during a social visit to a sick person is 'Wihangane!' This phrase, which is difficult to translate into English, literally means 'that you might bear it', or 'that you might endure'. Perhaps it is best translated into colloquial American English as 'Hang in there!' Two additional cultural-linguistic concepts of resilience relevant specifically to genocide survivors were 'kwongera kubaho' (to return to life [from death]) and 'gukomeza ubuzima' (to continue living) (Zraly and Nyiranyoye, 2010).

These sociocultural resources for coping with the genocide and its aftermath, as well as the everyday practices of muddling through terrible situations, fit well with a contextualised resilience model of recovery. They also establish the need for peacebuilding interventions to account for local cultural contexts and engage with grassroots actors. Yet, these micro-level modes of resilience can be hindered or completely undone by national or international interventions and the political power of elites.

\section{NATIONAL PROCESSES OF PEACEBUILDING, SYSTEMIC HINDRANCES AND LOCAL RESISTANCE}

After ending the genocide, the RPF military forces and transitional government sought to re-establish the rule of law. As citizens' basic needs began to be met, the government moved onto symbolic, social and legal forms of peacebuilding. Some of these efforts, such as removing race from bureaucracy and public discourse, resonated positively with adaptive peacebuilding efforts at the grassroots level. Other national efforts, especially those related to genocide commemoration and public memory, disrupted adaptive peacebuilding and undermined contextualised resilience in communities by interfering with local recovery efforts.

Among its first symbolic efforts to eradicate racist ideologies, the government eliminated 'race talk' from daily life. After the genocide, the government removed racial identification from all government bureaucracy, including the national identity cards that had determined many people's fates during the genocide, and discouraged use of the terms 'Hutu', 'Tutsi' and 'Twa'. In 2001, the government passed a law forbidding discussion of racial differences and the use of racial identification in public discourse (Republic of Rwanda, 2001). At face value, these policies appeared to promote positive adaptation to past violence. Racist ideologies had made genocide possible, and the national identity cards had helped identify potential victims. While these policies 
sought to heal the nation, they simultaneously helped the RPF political party to consolidate its power.

National unity was a foundational ideology of racial inclusion of the RPF rebel group. The RPF's ideology of national unity emphasised unifying aspects of Rwandan history and culture (i.e., shared language, culture, religious practices, etc.) and blamed racial division on European colonisers (Burnet, 2009: 84; Burnet, 2012: 151; Pottier, 2002: 109-129). In the aftermath of the genocide, the RPF-led government joined national unity and reconciliation:

$[\mathrm{R}]$ econciliation is short for national unity and national reconciliation. ... We believe that reconciliation will not come through forgetting the past, but in understanding why the past led to political turmoil and taking measures, however painful and slow, which will make our 'Never Again' a reality.

(cited in Burnet, 2012: 151)

National unity and reconciliation came to encompass a broad range of initiatives reorganising local government administration, formalising and nationalising genocide commemoration and mourning activities, changing the national symbols (i.e., flag, anthem, motto, shield), rewriting the constitution, creating re-education and solidarity camps and setting up grassroots courts to adjudicate genocide crimes. The RPF's approach to national unity and reconciliation was taught in schools and was ubiquitous in public discourse, "from political speeches to NGO conferences to sporting and music events' (Doughty, 2016: 3). National unity and reconciliation thus became the foundation for the new government's state-building programme and instilled RPF policy at its heart.

The RPF's approach interfaced not only with national and local systems in Rwanda but also with international systemic approaches to peacebuilding. Many international initiatives related to peacekeeping, peacebuilding, conflict resolution and transitional justice of the twenty-first century were directly modelled after initiatives tried in Rwanda. For example, United Nations (UN) peacekeeping regulations grew to encompass the use of force to protect civilians from gross human rights abuses in response to the UN peacekeeping mission's failure during the Rwandan genocide. The former UN High Commissioner for Refugees, Sadako Ogata (1990-2000), developed her concept of peaceful coexistence and piloted the project that became 'Imagine Coexistence' in Rwanda (Ogata, 2000). The UN Security Council created the International Criminal Tribunal for the former Yugoslavia (ICTY) and the ICTR as experiments that led to the eventual creation of the International Criminal Court. 
Despite these positive national and international contributions to peacebuilding in Rwanda, other national efforts disrupted resilience by supplanting local adaptations to past shocks and stressors resulting from mass violence. In particular, reconciliation efforts often worked against adaptive peacebuilding efforts that had emerged from civil society organisations or at the grassroots. In early 1995, Rwanda's government displaced family and community-level commemoration efforts with its own national project of commemoration that claimed to promote reconciliation but also reinforced the power of the new state (Burnet, 2012; Vidal, 2001, 2004). In essence, this change constituted a shift from locally led adaptive peacebuilding initiatives to formalised, systemic approaches that utilised some local practices of reconciliation but ultimately served to consolidate the RPF's political power.

While national reconciliation efforts were clearly needed, they were not always best adapted to local needs. In April 1995, the government organised the first annual genocide commemoration ceremony at the National Amahoro Stadium in Kigali. This first ceremony represented both Tutsi and Hutu as victims of the genocide, unlike subsequent national genocide commemorations. In a ceremony attended by President Pasteur Bizimungu, Vice President Paul Kagame, cabinet members, parliamentarians and international diplomats based in Kigali, the participants re-interred approximately 6,000 anonymous genocide victims alongside several well-known Hutu genocide victims (Pottier, 2002: 158; Vidal, 2001: 6). A Catholic priest, a Protestant pastor and a Muslim imam consecrated the mass grave beside the national stadium. In this way, Hutu and Tutsi were given joint recognition as victims of the genocide. The decision to recognise both Hutu and Tutsi genocide victims 'had emerged after debates in the cabinet' (Vidal, 2001: 7; author's translation).

As the RPF consolidated its hold on political power, public memory of the genocide disseminated through national genocide commemoration ceremonies shifted. This change created systemic hindrances to peacebuilding and privileged the traumatic memories of certain citizens over others. Stateled commemoration practices formalised the government's official history of the genocide and silenced dissent. Only certain social categories were allowed to speak publicly about the past or comment on government policies. Genocide survivor organisations spoke relatively freely in the public sphere, although the government maintained control over their leadership (Gready, 2010).

Later national genocide commemoration ceremonies globalised blame on Hutu and erected a Tutsi monopoly on suffering (Vidal, 2001: 7). Survivors of RPF-perpetrated killings were silenced, and the victims' families could not mourn their lost loved ones in public. In many cases, the victims of RPF killings were often buried in secret mass graves or in graves designated as 
genocide memorials. These public secrets were known by everyone but remained unspoken, creating an amplified silence surrounding RPFperpetrated violence experienced by Rwandans of all races (Burnet, 2012: 111-112). This resounding silence around RPF violence and ongoing human rights violations hindered adaptive peacebuilding efforts in local communities and prevented victims from positively adapting or healing. Even contextualised resilience is inherently political and may not support long-term prospects for positive peace.

Beyond the amplified silence surrounding certain forms of violence that took place during the civil war and after the genocide, Rwandan government discourse about the genocide and the country's history impeded reconciliation. Even if it was intended to achieve long-term good, the suppression of the terms 'Hutu', 'Tutsi' and 'Twa' in the wake of the genocide did not magically erase their importance in Rwandans' daily lives. Thus, people substituted new words for them: genocide survivor or victim for Tutsi, and genocide perpetrator, killer or prisoner for Hutu. Because this new terminology followed an absolutist logic of good and bad, it erased the possibility for acknowledgement of Hutu genocide victims or Tutsi perpetrators of violent crimes. The silence over RPF killings and the government's dominant discourse about the genocide created a memoryscape from which Hutu victims were erased. As a result, it laid the groundwork for genocide denial to persist among some Rwandans. From their perspective, the government's denials surrounding RPF abuses and exclusion of Hutu genocide victims made sotto voce allegations of a 'double genocide' plausible in some circles.

Politicisation of the genocide and public memory practices undermined adaptive peacebuilding and reconciliation efforts in local communities, and numerous systemic hindrances interfered as well. One of the most significant disruptions was recurring episodes of violence - whether perpetrated by civilians, Interahamwe militias, rebel insurgents or government security forces. After the genocide ended in July 1994, the new government security forces frequently used lethal force to capture alleged genocide perpetrators or to combat insurgents. Some genocide survivors attacked alleged perpetrators seeking revenge. As the new government re-established the rule of law, this violence largely subsided. Then, between 1997 and 1999, many regions of the country faced insurgent attacks and counterinsurgency operations by government security forces. Insurgent attacks reignited survivors' traumatic memories and intensified symptoms of post-traumatic stress disorder (PTSD) or psychosocial trauma. Violent episodes hindered individuals and communities from healing their traumas and destroyed trust where some communities had made progress. 
A final systemic hindrance that delayed recovery and hindered peacebuilding efforts was the extreme poverty of rural Rwandans and the marginalisation of genocide survivors. When people's basic needs (food, water, shelter, clothing) are not met, they are incapable of expending energy on healing trauma or repairing social relationships. The majority of Rwandans faced extreme poverty in the first years after the genocide; their only focus was on survival. For genocide survivors, many of whom were the sole survivor in an entire lineage, the deaths of loved ones produced traumatic memories as well as ongoing poverty and marginalisation. When I asked her about reconciliation, an elderly woman responded: 'How can you ask me about reconciliation? I'm here all alone. When I need water, there is no one to send to the spring. When I need wood for the fire, there is no one to chop it for me. When the fields need planting, there is no one to help me. I don't even have a grandchild to keep me company at night' (author interview, Rwanda, 2000).

\section{TRANSITIONAL JUSTICE, STATE POWER AND RESILIENCE}

Two particular transitional justice processes attempted to address the 1994 genocide of Tutsi in Rwanda: the ICTR - an ad hoc international court in Arusha, Tanzania - and a nation-wide system of grassroots courts in Rwanda, known as Gacaca. As conceived in their statutory and ideal form, both mechanisms came to serve as models for transitional justice worldwide. In practice, both institutions became entangled in various competing actors' political objectives. Because of its international focus, the ICTR had little impact inside Rwanda in terms of transitional justice, adaptive peacebuilding or resilience. The Gacaca courts, on the other hand, had significant impacts on the country. In the short term, they disrupted adaptive peacebuilding efforts and increased local conflict in Rwanda. In the long term, the Gacaca courts reinforced state power and RPF dominance in Rwanda, ensuring state stability but without positive peace through interpersonal reconciliation. Whether reinforcing state power constitutes resilience depends entirely on how resilience is defined and the weight given to state stability in that definition. At a minimum, transitional justice in Rwanda illustrates that resilience is an inherently political concept.

The UN Security Council created the ICTR in November 1994, "for the sole purpose of prosecuting persons responsible for genocide and other serious violations of international humanitarian law committed in the territory of Rwanda and Rwandan citizens responsible for genocide and other such violations committed in the territory of neighbouring states, between 1 January 1994 and 31 December 1994' (UN, 1994). In its twenty-year existence, the ICTR prosecuted seventy-six people for genocide or crimes against humanity and 
found sixty-two of them guilty. Its most significant achievement was the firstever conviction for the crime of genocide (Prosecutor $v$. Akayesu, 1998). The UN Security Council conceived of the ICTR as an important mechanism for ensuring 'international peace and security' (Wilson, 2011: 366). While the Tribunal is largely considered a success at the international level, it delivered limited justice to the Rwandan people. People prosecuted by the ICTR faced lesser penalties than those tried in Rwanda. Alleged perpetrators in Rwanda lived in overcrowded prisons where food and water were at times inadequate or unsanitary, while those judged by the ICTR enjoyed prisons equipped with fitness facilities, air conditioning and access to computers. The ICTR consumed vast resources, which could have been used to rehabilitate Rwanda's legal system and speed up justice efforts inside the country. The ICTR did little to promote adaptive peacebuilding in Rwanda, but it did help to ensure that several of the genocide's architects and many perpetrators who had fled the country were held accountable.

In Rwanda, the government initially set out to prosecute every single genocide perpetrator, from the leaders who organised the genocide down to the subsistence farmers who stole their neighbours' property (Waldorf, 2006: 3). This approach was formulated with the long-term goal of ensuring stability (and, perhaps, resilience) by focusing on deterrence rather than offering amnesties in exchange for truth-telling, as in the South African Truth and Reconciliation Commission process. Yet, the approach created an insurmountable backlog of cases which would have challenged any legal or penal system in the world, much less one destroyed by genocide. In 1995, the government passed a law to prosecute genocide crimes. In 1996, the first genocide trials began in Rwanda's formal courts; these cases resulted in the first convictions of genocide perpetrators and public executions in April 1997. By 1999, 150,000 prisoners accused of genocide crimes awaited trial in congested prisons that had been fashioned from warehouses or hastily expanded school dormitories (Human Rights Watch, 2000). The most optimistic analyses at the time estimated that the accused would await trial for decades. This situation undermined justice for survivors, who sought the truth about how their loved ones were killed, and the impossibly long wait for trials and abysmal detention conditions violated the rights of those accused of genocide crimes.

In the absence of state-based transitional justice interventions between 1994 and 2002, some families turned to a traditional conflict-resolution mechanism, known as gacaca (pronounced ga-cha-cha), to address harm inflicted during the genocide. In gacaca, local leaders called together the people in dispute, the residents of a hill and 'people of integrity' (inyangamugayo), who were usually respected elders, to establish the facts of the conflict and find a solution 
(Burnet, 2012: 196). After the genocide, some survivors found it expedient to resolve their conflicts over genocide crimes with kin, neighbours or business partners via a traditional gacaca process. The outcomes of these cases sometimes involved the payment of money, property, goods or services, ensuring the long-term livelihoods of victims and perpetrators. While these grassroots efforts at transitional justice were not widespread, they constitute another example of adaptive peacebuilding and community resilience.

In response to the immense caseload and inhumane prison conditions, the government transformed traditional gacaca into a nation-wide system of Gacaca courts, where local citizens served as judges, prosecutors, defenders and witnesses. The Gacaca courts became 'a central site for promoting national unity and restoring the social fabric' in the aftermath of genocide (Doughty, 2016: 3). They became the primary mechanism of transitional justice within the country. In a little over ten years, the Gacaca courts processed almost 2 million cases, 65 per cent of which resulted in guilty verdicts (BBC, 2012). Although they cleared the massive backlog of cases, their justice was limited. In exchange for full confessions, perpetrators' sentences were cut in half. Many perpetrators became eligible for release immediately after their sentencing. Genocide survivors often found that perpetrators' sentences were too light for the crimes committed (Rafferty, 2018). The prosecution, defendants and victims were denied legal representation, which constituted a violation of international legal standards. The falsely accused had little opportunity to prove their innocence and faced a grim set of options. They could confess to crimes they had not committed and receive early release (Burnet, 2012: 137), or they could remain in prison for years, awaiting a trial with the potential of a guilty verdict.

Many legal scholars concluded that justice in Rwanda was one-sided victors' justice (Longman, 2011; Oomen, 2005; Rettig, 2008; Thomson and Nagy, 2010; Waldorf, 2006). Gacaca and civilian courts did not have jurisdiction over killings or other atrocities perpetrated by RPF soldiers. These crimes were relegated to military courts. RPF soldiers prosecuted by the military courts usually received light sentences. Senior officers were rarely court-martialed for abuses against civilians (Human Rights Watch, 1997). The victims of RPF war crimes continue to feel that they have not received justice. In some communities' Gacaca courts, they tried to raise these issues, but the courts had no jurisdiction to hear these cases. From this perspective, transitional justice in Rwanda hindered adaptive peacebuilding and harmed resilience by leaving many citizens without a feeling of justice.

Early scholarship on the Gacaca courts focused on their ideal, intended form (Daly, 2002; Longman, 2006; Ntampaka, 1995; Staub, 2004; Tiemessen, 2004; Uvin, 2003; Wierzynska, 2004). These studies largely concluded that the 
Gacaca courts were an excellent model of transitional justice because they provided for truth, justice, restitution or reparations, healing, forgiveness and reconciliation. Phil Clark's study (2010) is illustrative of this mode of research. Clark (2010: 300) portrays the courts as a form of restorative justice intended to engage 'parties previously in conflict' in 'communal dialogue and cooperation', which are 'crucial to fostering reconciliation after genocide', and to punish 'those convicted of genocide and crimes against humanity ... explicitly in order to promote reconciliation'. He acknowledged that the gacaca process retraumatised genocide survivors and others or enflamed existing tensions where compensation was given grudgingly (Clark, 2010: 98-131). He also found that gacaca 'exacerbate[d] low-level conflicts between individuals and groups in the community' (Clark, 2010: 226). He concluded, however, that, taken as a whole, gacaca achieved its goals as a form of restorative justice (Clark, 2010: 353-355). From this perspective, the Gacaca courts appear to have supported adaptive peacebuilding and enhanced resilience.

A growing body of scholarship based on in-depth, empirical research on the practices of the Gacaca courts reached far less positive conclusions (Brounéus, 2008; Buckley-Zistel, 2005; Chakravarty, 2016; Doughty, 2016; Ingelaere, 2016; Rettig, 2008; Thomson, 2011). These studies conclude that the Gacaca courts failed to support inter-personal reconciliation, increased conflict and undermined trust. In short, transitional justice harmed adaptive peacebuilding and undermined resilience in local communities.

Truth has long been predicated as the foundation of transitional justice mechanisms (Abu-Nimer, 2001; Fletcher and Weinstein, 2002; Gibson, 2004; Hinton and O'Neill, 2009). While the Gacaca courts may have delivered a forensic truth (at least some of the time), they failed to produce a 'dialogical, narrative or healing' truth required for Rwandan understandings of conflict resolution and reconciliation (Ingelaere, 2009, 2016: 5). In my own research in rural and urban Rwanda, dialogical, narrative truth was a key element of virtually all successful, adaptive peacebuilding efforts (Burnet, 2012). Rather than producing truth, testimony (or silence) in Gacaca hearings became 'a form of alliance building' (Doughty, 2016: 107). The end result in many communities was that the Gacaca courts only produced partial truths about the genocide. Furthermore, this truth finding was conditioned by the threat of state power and potential punishment (Chakravarty, 2016; Doughty, 2016; Ingelaere, 2016). The Gacaca courts became a performative site that reinforced RPF dominance.

In the short term, the Gacaca courts dramatically increased conflict and undermined trust in adaptive peacebuilding efforts. The courts were a massive imposition on ordinary Rwandans over a period of ten years. At least once, but sometimes two or three days each week, people were required to participate 
in day-long hearings. This imposition took them away from their agricultural fields, their homes and their livelihoods. During the hearings, attendees often heard detailed, gruesome testimony about the genocide, which triggered traumatic memories for some and risked generating new trauma through secondary exposure for others. After testifying, many witnesses faced threats or physical violence as the families of the accused sought to silence them. Some survivors discovered that neighbours or friends with whom they had reestablished social ties in the ten years after the genocide had participated in the genocide or even killed their loved ones. Although the Gacaca courts relied on confession as a cornerstone and potentially restorative justice mechanism, 'once the courts were underway, they shifted from confessions to accusatory practices' (Ingelaere, 2016: 5). In their confessions, some perpetrators falsely implicated others as a way to inflict harm or seek revenge for matters unrelated to the genocide. All these effects dramatically increased mistrust, intensified conflict and even erupted into renewed physical violence.

In the long term, the Gacaca courts increased stability (and thus resilience) by reinforcing state power and RPF dominance. The Gacaca courts and their repetitive praxis over a ten-year period reinforced the ideas that conflict was bad, conciliation was good and that harmonious behavior [was] more civilized than disputing behavior, the belief that consensus is of greater survival value than controversy' (Nader, 1990: 2, cited in Doughty, 2016: 10). Because this view was backed by 'the threat of state punishment', including imprisonment, property forfeiture, fines, restitution to victims in the form of money or labour or compulsory community service, ordinary Rwandans conformed to the scripted reconciliation imposed through the Gacaca courts (Doughty, 2016: 10). Over time, the Hutu population acceded to this imposition because they saw no other good options. Thousands of Hutu adults actively participated in the entrenchment of RPF rule by participating in the Gacaca courts to secure reduced sentences, 'private gains in the form of personal vengeance or economic windfalls' or opportunities to secure their own political power (Chakravarty, 2016: 3). Rather than genuinely participating in a process of truth and reconciliation, they sought 'to protect or advance themselves' by submitting to RPF rule (Chakravarty, 2016: 3). Chakravarty's analysis of the Gacaca court system demonstrates how the courts reinforced RPF dominance at all levels of the state apparatus.

\section{REPARATIONS, ADAPTIVE PEACEBUILDING AND RESILIENCE}

Although the ICTR had little impact on adaptive peacebuilding and resilience in Rwanda, its successes and failures highlight the ways in which 
reparations, in all their diverse forms, have the potential to support adaptive peacebuilding and build resilient communities prepared to deal with intense conflict without descending into mass violence. Reparation efforts inside Rwanda provide clear evidence that reparations can support adaptive peacebuilding and enhance resilience.

In the early 1990s, international legal theory and practice had not yet discovered the fundamental importance of reparations to transitional justice. Thus, the UN Security Council failed to include reparations as part of the ICTR's mandate. Over the course of its operation and through its engagement with witnesses, the ICTR came to understand the foundational importance of victims' rights, restitution and reparations to recovery from mass violence. In 1998, the Rules of Procedure and Evidence were amended to extend the mandate of the Victims and Witness Support Unit to include 'physical and psychological rehabilitation' and short- and long-term plans for the protection of witnesses and their families (Evans, 2012: 95). The UN International Residual Mechanism for Criminal Tribunals, which took over ongoing duties when the ICTR closed in 2015, continues to provide healthcare and social services to hundreds of witnesses in Rwanda. While of minimal impact given the hundreds of thousands of Rwandan survivors, these efforts at least demonstrate an approach that incorporates restitution, reparations and victim support into international justice mechanisms. The mistakes made and lessons learned from the ICTR became the foundation for the multi-modal reparations for victims of gross human rights violations outlined in UN General Assembly Resolution 60/147 of 16 December 2005. In the eleven years between the ICTR's creation and this resolution, legal theory and empirical evidence about reparations grew exponentially. The resolution delineated the many complementary forms that reparations can take: restitution, compensation, rehabilitation, satisfaction and guarantees of non-repetition.

In the quarter century following the genocide, the Rwandan government provided many complementary forms of reparations to genocide victims, at times with support from the international community. Reparations included a variety of direct assistance programmes ranging from food aid, housing assistance, medical treatment, health insurance or tuition. Yet, only officially recognised and registered survivors benefitted from these programmes. Many survivors of mixed parentage and Hutu or Twa genocide victims did not receive anything (Burnet, 2012: 159). Perhaps more importantly, these forms of government assistance often came late, after months or years of misery. They were almost always insufficient to raise survivors out of poverty. At times, they were discontinued due to budgetary constraints.

Many international and government initiatives in Rwanda sought to rehabilitate victims physically and psychologically in the first ten years after 
the genocide. While these programmes helped, they were all funded through emergency humanitarian aid. Thus, the programmes often stopped after a few years or trained Rwandans in psychosocial support without creating a permanent infrastructure to employ them or provide services. For example, hundreds of trauma counsellors were trained between 1997 and 2000, but the international community only funded civil society organisations to employ them for a few years. Then, the government did not create permanent positions. As a result, few genocide victims received the ongoing psychological support that trauma survivors often need to thrive. The national genocide commemoration ceremonies and genocide memorial sites provided victims with symbolic reparations. Yet, genocide memorial sites languished for more than a decade before coming to fruition. In addition, politics entwined these symbolic reparations with state-building, thus limiting their healing effects.

The Rwandan Genocide Statute (Law No. 08/96) and the Gacaca courts provided restitution to both individual victims and communities as part of their mandates. Where judges determined that property had been looted or destroyed, perpetrators or their families were required to compensate the victims. These judgments came ten to fifteen years after the genocide. While symbolically powerful, they arrived too late for victims who were in desperate need (homeless, destitute, malnourished) between 1994 and 2004. In addition, survivors rarely received full restitution because the perpetrators and their families were too impoverished to complete the payments. The vast majority of perpetrators given reduced sentences in Gacaca were also required to complete community service projects, early on through labour camps, and later a few days each week or month from their homes.

The Gacaca courts and the ICTR both demonstrate the need for multimodal reparations to victims of gross human rights violations and mass violence. Restitution and diverse forms of reparations can help victims build meaningful lives even if they cannot make them whole or help them to 'bounce back with minimal loss and disturbance' (Barrios, 2016: 28). This assistance must come quickly to have a significant impact on adaptive peacebuilding and resilience. Diverse forms of reparations, especially those that integrate the principles of adaptive peacebuilding at a community level, can help reweave the social fabric and build more resilient communities. These forms of reparations range from the symbolic - including religious mourning rituals, memorials and public commemorations - to the material - such as compensation for harm done and support to survivors - to public disclosure of the truth. To be effective, these forms of reparations must be designed and implemented through approaches that fully integrate local voices. Regional, 
national or international programmes must be developed to accommodate high levels of local variation.

\section{CONCLUSION}

Rwanda's post-genocide recovery and state-building reinforced RPF political, economic and social dominance. Even when multi-system change leads to greater societal stability and the ability to absorb disturbance and avoid future stress exposure, this short-term appearance of resilience may hide new hierarchies and societal divides that risk generating new conflict. Resilience as a transformational process is still conditioned by politics. Politics must not be ignored in resilience models of recovery. In Rwanda, transitional justice ultimately benefitted the nation-state at the expense of community healing and displaced local adaptive peacebuilding efforts that were often the most successful in promoting reconciliation.

The lessons learned from adaptive peacebuilding and transitional justice in Rwanda point to the importance of tending to local-level needs and concerns in post-genocide crises. Reparations must encompass all victims of gross human rights abuses to avoid creating hierarchies of suffering or new divisions within society. Emphasis on rebuilding social processes of dialogue and reciprocity can help communities heal even when these efforts are not undertaken with peacebuilding or resilience in mind. Adaptive peacebuilding's emphasis on process instead of end states adds an important dimension to resilience models of recovery. Resilience models must consider micro- and macro-level concerns and pay attention to the impact of political power on outcomes.

\section{REFERENCES}

Abu-Nimer, M. (2001). Reconciliation, Justice, and Coexistence: Theory and Practice. Lanham, MD: Lexington Books.

Autesserre, S. (2014). Peaceland: Conflict Resolution and the Everyday Politics of International Intervention. Cambridge: Cambridge University Press.

Barrios, R. E. (2016). Resilience: A commentary from the vantage point of anthropology. Annals of Anthropological Practice, 40(1), 28-38.

BBC. (2012). Rwanda 'gacaca' genocide courts finish work. www.bbc.co.uk/news/worldafrica-18490348 (accessed 6 May 2020).

Brounéus, K. (2008). Truth-telling as talking cure? Insecurity and retraumatization in the Rwandan gacaca courts. Security Dialogue, 39(1), 55-76.

Buckley-Zistel, S. (2005). 'The truth heals?' Gacaca jurisdictions and the consolidation of peace in Rwanda. Die Friedens-Warte, 80(1-2), 113-130. 
Burnet, J. E. (2009). Whose genocide? Whose truth? Representations of victim and perpetrator in Rwanda. In: A. L. Hinton and K. L. O’Neill (eds.), Genocide: Truth, Memory and Representation. Durham, NC: Duke University Press, pp. 80-110.

Burnet, J. E. (2012). Genocide Lives in Us: Women, Memory, and Silence in Rwanda. Madison, WI: University of Wisconsin Press.

Chakravarty, A. (2016). Investing in Authoritarian Rule: Punishment and Patronage in Rwanda's Gacaca Courts for Genocide Crimes. Cambridge: Cambridge University Press.

Clark, P. (2010). The Gacaca Courts, Post-Genocide Justice and Reconciliation in Rwanda: Justice without Lawyers. Cambridge: Cambridge University Press.

Cutter, S. L., Barnes, L., Berry, M., Burton, C., Evans, E., Tate, E. and Webb, J. (2008). A place-based model for understanding community resilience to natural disasters. Global Environmental Change, 18(4), 598-606.

Daly, E. (2002). Between punitive and reconstructive justice: The gacaca courts in Rwanda. New York University Journal of International Law and Politics, 34(2), $355-396$.

de Coning, C. (2018). Adaptive peacebuilding. International Affairs, 94(2), 301-317.

de Coning, C. (2020). Insights from complexity theory for peace and conflict studies. In O. Richmond and G. Visoka (eds.), The Palgrave Encyclopedia of Peace and Conflict Studies. Cham: Palgrave Macmillan. https://doi.org/10.1007/978-3-030-11 795-5_134-1

Des Forges, A. (1999). Leave None to Tell the Story: Genocide in Rwanda. New York: Human Rights Watch.

Doughty, K. (2016). Remediation in Rwanda: Grassroots Legal Forums. Philadelphia, PA: University of Pennsylvania Press.

Evans, C. (2012). The Right to Reparation in International Law for Victims of Armed Conflict. Cambridge: Cambridge University Press.

Fletcher, L. E. and Weinstein, H. M. (2002). Violence and social repair: Rethinking the contribution of justice to reconciliation. Human Rights Quarterly, 24(3), 573-639.

Foxen, P. (2010). Local narratives of distress and resilience: Lessons in psychosocial well-being among the K'iche' Maya in postwar Guatemala. The Journal of Latin American and Caribbean Anthropology, 15(1), 66-89.

Galtung, J. (1969). Violence, peace and peace research. Journal of Peace Research, 6(3), $167-191$.

Galtung, J. (1990). Cultural violence. Journal of Peace Research, 27(3), 291-305.

Gibson, J. L. (2004). Does truth lead to reconciliation? Testing the causal assumptions of the South African truth and reconciliation process. American Journal of Political Science, 48(2), 201-217.

Gready, P. (2010). 'You're either with us or against us': Civil society and policy making in post-genocide Rwanda. African Affairs, 109(437), 637-657.

Hinton, A. L. and O’Neill, K. L. (eds.) (2009). Genocide: Truth, Memory, and Representation. Durham, NC: Duke University Press.

Holling, C. (1973). Resilience and stability of ecological systems. Annual Review of Ecology and Systematics, 4, 1-23.

Human Rights Watch. (1997). Prosecuting genocide in Rwanda: A lawyers' committee report on the ICTR and national trials. www.unwatch.com/rwanda.html (accessed 13 August 2017). 
Human Rights Watch. (2000). Rwanda. In: World Report 2000. www.hrw.org/wrzk/Af rica-o8.htm\#TopOfPage (accessed 19 May 2018).

Ingelaere, B. (2009). 'Does the truth pass across the fire without burning?' Locating the short circuit in Rwanda's gacaca courts. The Journal of Modern African Studies, 47(4), 507-528.

Ingelaere, B. (2016). Inside Rwanda's Gacaca Courts: Seeking Justice After Genocide. Madison, WI: University of Wisconsin Press.

Koopman, S. (2011). Alter-geopolitics: Other securities are happening. Geoforum, 42(3), $274-284$.

Longman, T. (2006). Justice at the grassroots? Gacaca trials in Rwanda. In N. RohtArriaza and J. Mariezcurrena (eds.), Transitional Justice in the Twenty-First Century: Beyond Truth versus Justice. Cambridge: Cambridge University Press, pp. 206-228.

Longman, T. (2011). Limitations to political reform: The undemocratic nature of transition in Rwanda. In S. Straus and L. Waldorf (eds.), Remaking Rwanda: State Building and Human Rights after Mass Violence. Madison, WI: University of Wisconsin Press, pp. 25-47.

Mironko, C. and Cook, S. (1996). The linguistic formulation of emotion in Rwanda. In: Texas Linguistic Forum (TLF), vol. 4. Austin, TX: University of Texas Press.

Nader, L. (1990). Harmony Ideology: Justice and Control in a Zapotec Mountain Village. Stanford, CA: Stanford University Press.

Ntampaka, C. (1995). Le retour à la tradition dans le règlement des différends: Le gacaca du Rwanda. Dialogue, 186, 95-104.

Ogata, S. (2000). Keynote Speech by the UN High Commissioner for Refugees, at the International Symposium on Human Security. www.reliefweb.int/report/afghanistan/k eynote-speech-mrs-sadako-ogata-un-high-commissioner-refugees-international (accessed 29 March 2020).

Oomen, B. (2005). Donor-driven justice and its discontents: The case of Rwanda. Development and Change, 36(5), 887-910.

Pottier, J. (2002). Re-Imagining Rwanda: Conflict, Survival and Disinformation in the Late Twentieth Century. Cambridge: Cambridge University Press.

Prosecutor $v$. Jean-Paul Akayesu. (1998). ICTR Trial Chamber Judgment, ICTR-g64-T, 2 September 1998.

Rafferty, J. (2018). 'I wanted them to be punished or at least ask us for forgiveness': Justice interests of female victim-survivors of conflict-related sexual violence and their experiences with gacaca. Genocide Studies and Prevention: An International Journal, 12(3), 95-118.

Republic of Rwanda. (2001). Law No. 47/2001 of December 2001 Instituting Punishment for Offences of Discrimination and Sectarianism. Official Gazette of the Republic of Rwanda, Special Issue, December 2001.

Republic of Rwanda. (2004). Denombrement des victimes du génocide. Kigali: Ministry of Local Government, Communal Development and Social Affairs (MINALOC).

Rettig, M. (2008). Gacaca: Truth, justice and reconciliation in postconflict Rwanda? African Studies Review, 51(3), 25-50.

Sherrieb, K., Norris, F. and Galea, S. (2010). Measuring capacities for community resilience. Social Indicators Research, 99(2), 227-247.

Staub, E. (2004). Justice, healing and reconciliation: How the people's courts in Rwanda can promote them. Peace and Conflict: Journal of Peace Psychology, 10(1), $25-32$. 
Straus, S. (2006). The Order of Genocide: Race, Power, and War in Rwanda. Ithaca: Cornell University Press.

Thomson, S. M. (2011). The darker side of transitional justice: The power dynamics behind Rwanda's gacaca courts. Africa, 81(3), 373-390.

Thomson, S. M. and Nagy, R. (2010). Law, power and justice: What legalism fails to address in the functioning of Rwanda's gacaca courts. International Journal of Transitional Justice, 5(1), 11-30.

Tiemessen, A. (2004). After Arusha: Gacaca justice in post-genocide Rwanda. African Studies Quarterly, 8(1), 57-76.

Ungar, M. (2008). Resilience across cultures. The British Journal of Social Work, 38(2), 218-235.

United Nations. (1994). Security Council Resolution 955 [S/RES/955], Establishment of the International Criminal Tribunal for Rwanda. www.refworld.org/docid/3boo f $2742 \mathrm{c}$.html (accessed 14 March 2020).

United Nations. (1999). Report of the independent inquiry into actions of the United Nations during the 1994 genocide in Rwanda. https:/iccforum.com/media/back ground/reparations/2006-03-21_UN_General_Assembly_Resolution_6o-147_(Englis h).pdf (accessed 15 March 2020).

Uvin, P. (1998). Aiding Violence: The Development Enterprise in Rwanda. Hartford, CT: Kumarian Press.

Uvin, P. (2003). The gacaca tribunals in Rwanda. In D. Bloomfield, T. Barnes and L. Huyse (eds.), Reconciliation After Violent Conflict. Stockholm: International IDEA, pp. 116-121.

Verwimp, P. (2003). Testing the double-genocide thesis for Central and Southern Rwanda. Journal of Conflict Resolution, 47(4), 423-442.

Vidal, C. (2001). Les commémorations du génocide du Rwanda. Les Temps Modernes, $613,1-46$.

Vidal, C. (2004). La commémoration du génocide au Rwanda: Violence symbolique, memorization forcée et histoire officielle. Cahiers d'études Africaines, 44, 575-592.

Waldorf, L. (2006). Mass justice for mass atrocity: Rethinking local justice as transitional justice. Temple Law Review, 79(1), 1-87.

Wierzynska, A. (2004). Consolidating democracy through transitional justice: Rwanda's gacaca courts. New York University Law Review, 79(5), 1934-1969.

Wilkinson, M. T. and D'Angelo, K. A. (2019). Community-based accompaniment and social work - A complementary approach to social action. Journal of Community Practice, $27(2), 151-167$.

Wilson, T. Y. N. (2011). Procedural developments at the International Criminal Tribunal for Rwanda (ICTR). The Law and Practice of International Courts and Tribunals, $10(2), 351-380$.

Zraly, M. and Nyirazinyoye, L. (2010). Don't let the suffering make you fade away: An ethnographic study of resilience among survivors of genocide-rape in Southern Rwanda. Social Science and Medicine, 70(10), 1656-1664. 